\title{
Sustainable Transportation Strategies in Baghdad City: Shaab - Selekh Intersection
}

\author{
Areej Muhy Abdulwahab, Muntathar Ahmed Bader ${ }^{2}$ \\ Department. of Roads and Transportation Engineering, College of Engineering, Mustansiriyah University \\ eng.areej.m@uomustansiriyah.edu.iq
}

\begin{abstract}
Traffic congestion is the main traffic problem in major cities, which increases the psychological and health pressures on road users and society, as well as increasing the associated economic costs such as increasing fuel consumption and increasing the loss of cars, as well as increasing polluting emissions to the environment.
\end{abstract}

The intersection of Shaab - Selekh in Baghdad city is one of the most important intersections for linking the center of Baghdad in the northern provinces. It is characterized by high traffic density, especially in the peak hours of morning and evening caused by congested traffic congestion, delay in the time of the trip, causing waste of a lot of time, cost, inconvenience and reduce the level of service.

The research aims to know the level of service in the intersection and propose solutions that adopt sustainable transport strategies to improve the level of service and reduce congestion traffic at the intersection

Keywords:Sustainable Transport, Strategies, City of Baghdad, Avoidance Strategy, Improvement Strategy.

\section{Introduction}

Economic, environmental and social dimensions are regarded as the triple-bottom-line principle of sustainability, the interrelation among transportation and the three dimensions can be interpreted as what has shown in (Figure 1) (1).

According to the Centre for Sustainable Transportation, a sustainable transportation system is one that (2):

- $\quad$ Allows the basic access needs of individuals, societies to be met safely. It is a manner consistent with human and ecosystem health, with equity within and between generations;

- Is affordable, operates efficiently, offers choice of transport mode, supports a vibrant economy; limits emissions and waste within the planets ability to absorb them, minimizes consumption of non-renewable resources,

Limits consumption of renewable resources to sustainable yield level, reuses and recycles its component, and minimize the use of land and the production of noise

Paper History: (Received:30-4-2019,Accepted:15-5-

2019)

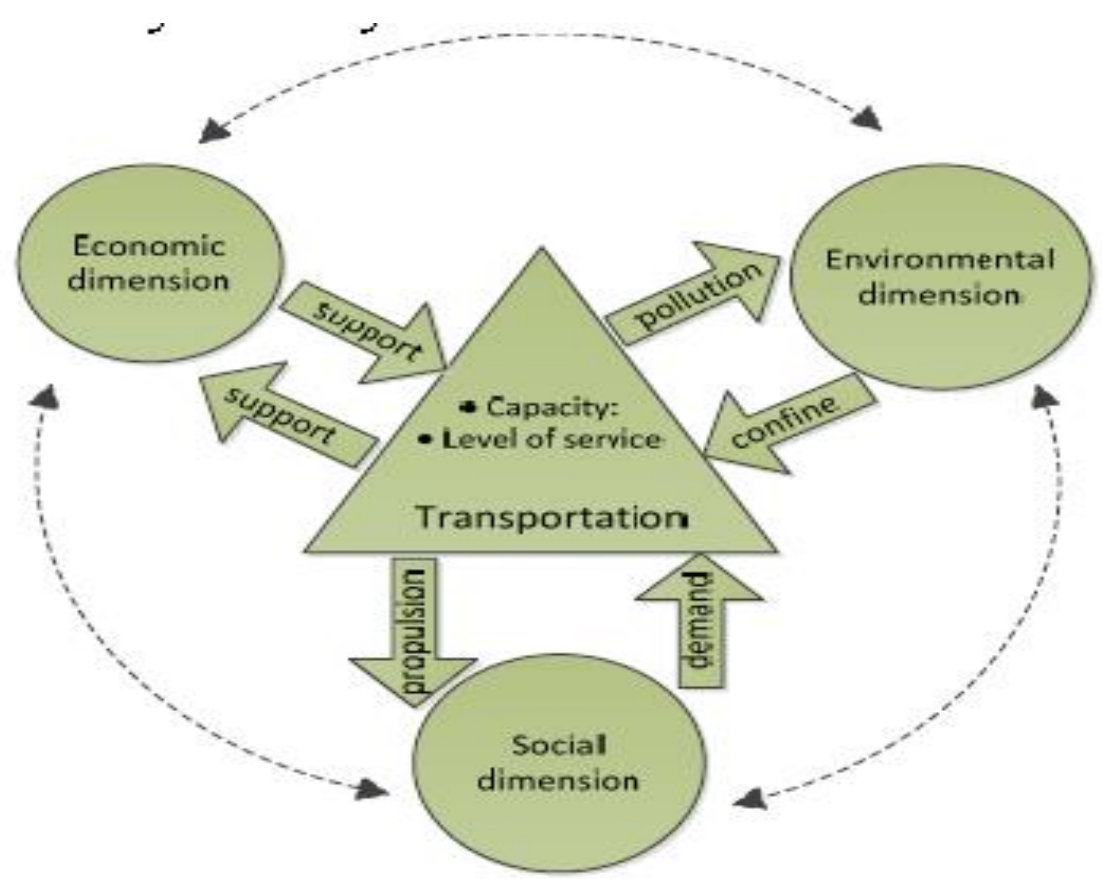

Fig. 1: The Interrelation Among Transportation and The Three Dimensions of Sustainability. (1) 
Strategies and policies for sustainable transport planning Includes the following (3):

1) Avoid Strategy: Avoid unnecessary travel and reduce trip distance. This strategy can be achieved through the following policies:

- Formally integrate land-use and transport planning processes and related institutional arrangements at the city level.

- Achieve mixed-uses development and medium-tohigh densities along key corridors within cities through appropriate land-use policies and provide people has oriented local access, and actively promote transit-oriented development (TOD) when introducing new public transport infrastructure.

The "Avoid" strategy is described first since, if its policies are applied in comprehensive way, it can have a great impact on urban transport, provide great social, economic and environmental benefits.

2) Shift Strategy: Moving towards more sustainable modes. This strategy can be achieved through the following policies:

- Require Non-Motorized Transport (NMT) components in transport master plans and prioritize transport infrastructure investments to NMT, including wide-scale improvements to pedestrian and bicycle facilities, development of facilities for intermodal connectivity, and adoption of complete street design standards, wherever feasible.

- Improve public transport services are including high quality, and affordable services on dedicated infrastructure along major arterial corridors in the city and connect with feeder services into residential communities

- $\quad$ Reduce the urban transport modal share of private has motorized vehicles through Transportation Demand Management (TDM) measures, including pricing measures that integrate congestion, safety, and pollution costs. It is aimed at gradually for reducing price distortions that directly or indirectly encourage driving, motorization, and sprawl (4).

- Achieve significant shifts to more sustainable modes of inter-city passenger and goods transport, including priority for high-quality long-distance bus, inland water transport, high-speed rail over car and air passenger travel. It is priority for train and barge freight over truck and air freight by building supporting infrastructure such as dry inland ports.

The shift approach can be the second most potent means for delivering sustainable urban transport if implemented properly. If one can implement Avoid and Shift strategies in one city, most of the hard work has been done, though more can be still improved.

3) Improve Strategy: Improve transport practices and technologies. This strategy can be achieved through the following policies:

- Support work towards more sustainable transport fuels and technologies, for including greater market penetration of options such as vehicles operating on electricity generated from renewable sources, hybrid technology and natural gas.

- Cities can support catalyze national auto fuel economy targets, plans, policies, standards by adopting locally appropriate incentives that aid the adoption and use of cleaner, more fuel-efficient vehicles.

- Enforce standards for fuel quality and tailpipe emissions for all vehicle types.

- Enforce vehicle testing, compliance regimes, including formal vehicle registration systems, appropriates periodic vehicle inspection and maintenance (I/M) requirements set out by national authority.

- Adopt Intelligent Transportation Systems (ITS), is such as electronic fare and road user charging systems, transport control centers, and real-time user information, when applicable (5).

- Achieve has improved freight transport efficiency.

- This measure hasn't generally seen as the most crucial to achieve substantial benefits in the short and long term for urban transport, it is an important complement to the Avoid and Shift measures, can achieve incremental benefits for society, the environment and the economy.

4) Protection Strategy: People first policy with a focus to protect people and environment. This strategy can be achieved through the following policies:

- Work towards zero-fatality policy with respect to road, rail, waterway safety, implement appropriate road design and infrastructure, speed control, traffic calming strategies.

- Promote monitoring of the health impacts from transport emissions and noise.

- Enforce national air quality and noise standards.

- Implement sustainable low-carbon transport measures.

- Adopt social equity as a planning and design criteria in the development and implementation of transport infrastructure projects.

- Encourage innovative financing mechanisms for sustainable transport infrastructure and operations through measures.

- Encourage has widespread distribution of information awareness on sustainable transport to all levels of government and to the public.

- Develop dedicated and funded institutions address sustainable transport-land use policies and implementation.

The transport sector in Iraq suffers from inefficiency and efficiency in its performance and development of other sectors (6).

Baghdad city suffers from various transport problems, including weak street capacity, with the number of cars increasing significantly, especially after 2003, as well as the age of the transport network and its lack of expansion with the increase in population (7). 


\section{Study Area and Data Collection}

The intersection of the shaab - Selekh has chosen as a study area for its importance and its distinctive location, which is considered the most important axes of the city of Baghdad, which is connected to the neighboring and northern governorates (Figure 2). The morning peak hours (7:00 am
- 9:00 am) and the evening peak hours (1:00-3) : $00 \mathrm{pm})$ for a period of 6 days (Saturday - Thursday) to determine the traffic volumes for the purpose of analysis, knowledge of the level of service (LOS) and the preparation of proposals to address traffic congestion problems at the intersection

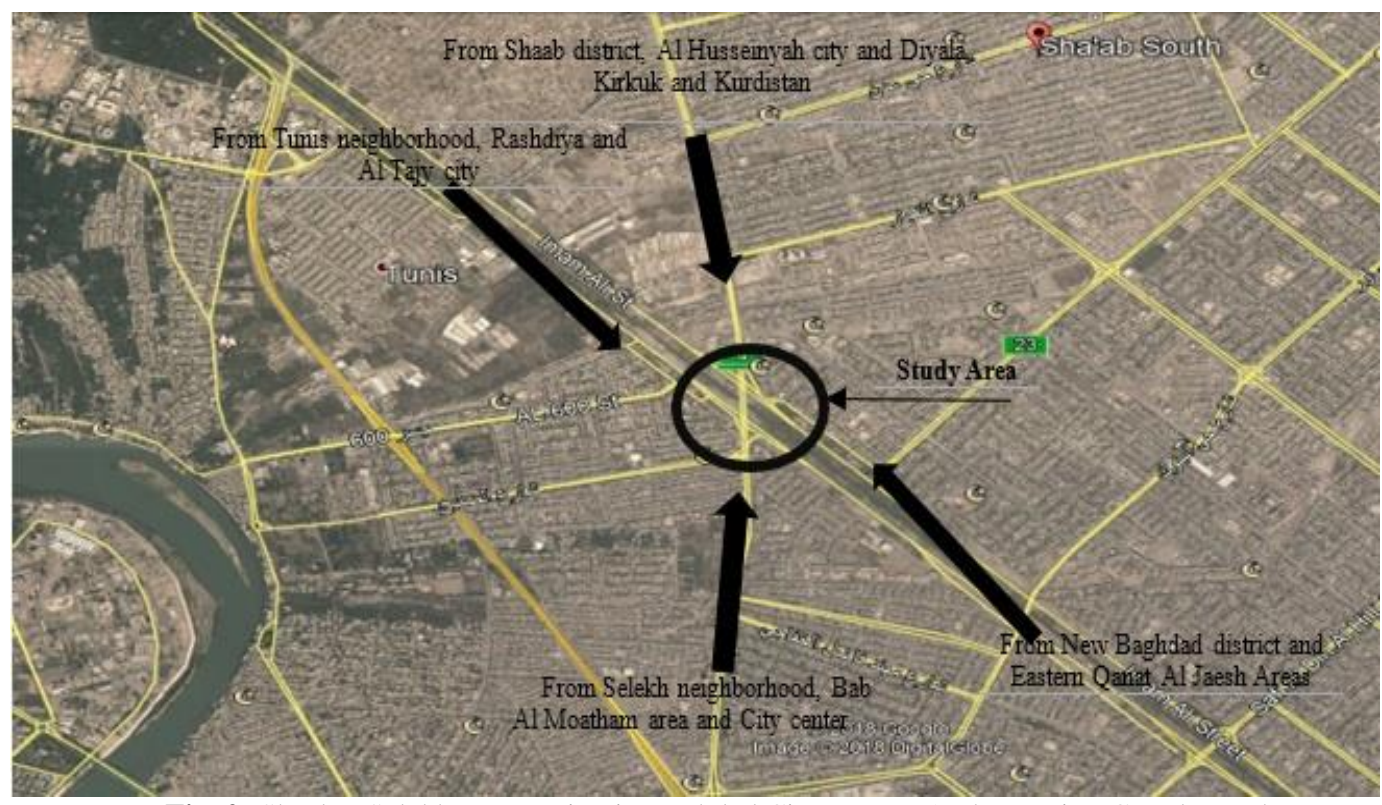

Fig. 2: Shaab - Selekh Intersection in Baghdad City - Iraq. Authors using Google Earth

\section{Analysis of Traffic Volumes in the Study Area}

It has been widely acceptable to utilize the American Highway Capacity Manual (HCM) in analyzing local transportation facilities (8). The traffic volume collection process has adopted using a program (HCS) (9) to knowledge the level of service in the intersection, as well as analysis the data is descriptive and quantified to find out the causes of congestion at the intersection. They are as follows:

First: On the overall level of traffic volumes Table (1) shows the following:

1) According to Axises: The axises are divided into the study area to (Shaab, Selekh, AL_Qanna), and the table 1 shows that the highest percentage of traffic volumes coming from the direction of the Shaab by $36 \%$ followed by the coming of Selekh by $34 \%$ and $30 \%$ coming from AL_Qanna.

This indicates is axis extending from the center of the city that crossing the intersection (the study area) to the city of Shaab and the two directions. It is the main axis of the traffic volumes for coming from the Shaab area and outside the borders of the master plan of the Baghdad city such as Bob Sham and Husseiniya and other governorates such as Diyala and Northern Governorates.
2) According to Days: Table (1) shows the highest volume of traffic on Sunday has $21.9 \%$, followed by Monday at $17.9 \%$, Tuesday at $17.1 \%$, followed by Wednesday at $16.9 \%$ and then on Thursday by $15.6 \%$, And the lowest traffic volume is on Saturday at $10.5 \%$.

The difference between the highest and lowest traffic volume is more than $10 \%$. This is result for attracting ,land use in the center of the city such as administrative educational and health services The official workhas started on Sunday and ended on Thursday. Most employees, students and auditors go to official and nonofficial institutions. 
Diyala Journal of Engineering Sciences Vol. 13, No. 01, March 2020, pages 66 -77

\begin{tabular}{|c|c|c|c|c|c|c|c|c|c|c|}
\hline \multicolumn{11}{|c|}{ Table 1: Traffic Volume in Case Study } \\
\hline Day & Time & Mode & SELEKH & SHAAB & ALQANNA & To & & $\%$ & Total & $\%$ \\
\hline \multirow{4}{*}{ Saturday } & \multirow{2}{*}{$\begin{array}{c}7: 00- \\
9: 00 \\
\text { am }\end{array}$} & $\begin{array}{c}\text { Passenger } \\
\text { car }\end{array}$ & 2104 & 2066 & 2139 & 6309 & \multirow[b]{2}{*}{8477} & \multirow[b]{2}{*}{$5.2 \%$} & \multirow{4}{*}{17012} & \multirow{4}{*}{$10.5 \%$} \\
\hline & & $\begin{array}{l}\text { Heavy } \\
\text { vehicle }\end{array}$ & 724 & 777 & 667 & 2168 & & & & \\
\hline & \multirow{2}{*}{$\begin{array}{c}1: 00- \\
3: 00 \\
\text { pm }\end{array}$} & $\begin{array}{c}\text { Passenger } \\
\text { car }\end{array}$ & 2380 & 1752 & 2050 & 6182 & \multirow{2}{*}{8535} & \multirow{2}{*}{$5.3 \%$} & & \\
\hline & & $\begin{array}{c}\text { Heavy } \\
\text { vehicle }\end{array}$ & 830 & 815 & 708 & 2353 & & & & \\
\hline \multirow{4}{*}{ Sunday } & \multirow{2}{*}{$\begin{array}{c}7: 00- \\
9: 00 \\
\text { am }\end{array}$} & $\begin{array}{c}\text { Passenger } \\
\text { car }\end{array}$ & 4094 & 5000 & 4172 & 13266 & \multirow{2}{*}{16003} & \multirow{2}{*}{$9.9 \%$} & \multirow{4}{*}{35599} & \multirow{4}{*}{$21.9 \%$} \\
\hline & & $\begin{array}{c}\text { Heavy } \\
\text { vehicle }\end{array}$ & 788 & 1174 & 775 & 2737 & & & & \\
\hline & \multirow{2}{*}{$\begin{array}{c}1: 00- \\
3: 00 \\
\text { pm }\end{array}$} & $\begin{array}{c}\text { Passenger } \\
\text { car }\end{array}$ & 5382 & 5083 & 5218 & 15683 & \multirow{2}{*}{19596} & \multirow{2}{*}{$12.1 \%$} & & \\
\hline & & $\begin{array}{l}\text { Heavy } \\
\text { vehicle }\end{array}$ & 1320 & 1461 & 1132 & 3913 & & & & \\
\hline \multirow{4}{*}{ Monday } & \multirow{2}{*}{$\begin{array}{c}7: 00- \\
9: 00 \\
\text { am }\end{array}$} & $\begin{array}{c}\text { Passenger } \\
\text { car }\end{array}$ & 3783 & 3752 & 3707 & 11242 & \multirow{2}{*}{14203} & \multirow{2}{*}{$8.8 \%$} & \multirow{4}{*}{29089} & \multirow{4}{*}{$17.9 \%$} \\
\hline & & $\begin{array}{l}\text { Heavy } \\
\text { vehicle }\end{array}$ & 1024 & 1054 & 883 & 2961 & & & & \\
\hline & \multirow{2}{*}{$\begin{array}{c}1: 00- \\
3: 00 \\
\mathrm{pm}\end{array}$} & $\begin{array}{c}\text { Passenger } \\
\text { car }\end{array}$ & 4080 & 4135 & 3448 & 11663 & \multirow{2}{*}{14886} & \multirow{2}{*}{$9.2 \%$} & & \\
\hline & & $\begin{array}{c}\text { Heavy } \\
\text { vehicle }\end{array}$ & 1210 & 1210 & 803 & 3223 & & & & \\
\hline \multirow{4}{*}{ Tuesday } & $\begin{array}{l}7: 00- \\
0 \cdot 00\end{array}$ & $\begin{array}{c}\text { Passenger } \\
\text { car }\end{array}$ & 3476 & 3655 & 3413 & 10544 & & & & \\
\hline & $\begin{array}{l}9: 00 \\
\text { am }\end{array}$ & $\begin{array}{l}\text { Heavy } \\
\text { vehicle }\end{array}$ & 995 & 1129 & 938 & 3062 & 13606 & $8.4 \%$ & & \\
\hline & 1:00- & $\begin{array}{c}\text { Passenger } \\
\text { car }\end{array}$ & 3661 & 3601 & 3353 & 10615 & & & 27740 & $17.1 \%$ \\
\hline & $\begin{array}{l}3: 00 \\
\text { pm }\end{array}$ & $\begin{array}{c}\text { Heavy } \\
\text { vehicle }\end{array}$ & 1237 & 1258 & 1024 & 3519 & 14134 & $8.1 \%$ & & \\
\hline & $\begin{array}{l}7: 00- \\
0 \cdot 00\end{array}$ & $\begin{array}{c}\text { Passenger } \\
\text { car }\end{array}$ & 3211 & 3554 & 2617 & 9382 & 11850 & 730 & & \\
\hline Wednesday & $\begin{array}{l}9.00 \\
\text { am }\end{array}$ & $\begin{array}{l}\text { Heavy } \\
\text { vehicle }\end{array}$ & 879 & 830 & 768 & 2477 & 11059 & $1.0 \%$ & 27417 & $169 \%$ \\
\hline weanesday & 1:00- & $\begin{array}{c}\text { Passenger } \\
\text { car }\end{array}$ & 4205 & 4593 & 3554 & 12352 & 15558 & $96 \%$ & $2 / 417$ & $10.9 \%$ \\
\hline & $\begin{array}{l}3: 00 \\
\text { pm }\end{array}$ & $\begin{array}{l}\text { Heavy } \\
\text { vehicle }\end{array}$ & 1207 & 1153 & 846 & 3206 & 15558 & $9.6 \%$ & & \\
\hline & $\begin{array}{l}7: 00- \\
0 \cdot 00\end{array}$ & $\begin{array}{c}\text { Passenger } \\
\text { car }\end{array}$ & 3139 & 3127 & 2510 & 8776 & 10911 & $67 \%$ & & \\
\hline Thursdav & $\begin{array}{l}9.00 \\
\text { am }\end{array}$ & $\begin{array}{l}\text { Heavy } \\
\text { vehicle }\end{array}$ & 733 & 691 & 711 & 2135 & 10911 & $0.1 \%$ & 25356 & $156 \%$ \\
\hline Inursaly & 1:00- & $\begin{array}{c}\text { Passenger } \\
\text { car }\end{array}$ & 3883 & 4475 & 3114 & 11472 & 14445 & $89 \%$ & 25350 & $15.0 \%$ \\
\hline & $\begin{array}{l}3: 00 \\
\mathrm{pm}\end{array}$ & $\begin{array}{l}\text { Heavy } \\
\text { vehicle }\end{array}$ & 1053 & 1085 & 835 & 2973 & 14445 & $8.9 \%$ & & \\
\hline & Total & & 55398 & 57430 & 49385 & 162213 & & & & \\
\hline & & & $34.2 \%$ & $35.4 \%$ & $30.4 \%$ & & & & & \\
\hline & & & & Authors & ng HSC & & & & & \\
\hline
\end{tabular}


Second: by the details of traffic volumes shows the following:

1) According to Times: (Table 1) shows the following:

- The highest traffic volume is in the evening peak hour (1:00 to 3:00) on Sunday, except for the traffic volume of morning and evening peak hours on Saturday.

- The highest volume of evening traffic volume has at $12.1 \%$ on Sunday, followed by a high of $9.6 \%$ on Wednesday. The lowest traffic volume on Saturday was $5.3 \%$.

- It shows that Sunday, Wednesday and Thursday are the most varied in the evening, morning peak hours due to the increase of flights in and out of the Baghdad city for various purposes, while it is being stable on Saturdays, Monday and Tuesday.

- The highest peak morning traffic volume on Sunday is $9.9 \%$, trailing from Sunday to Thursday. Saturday's lowest is $5.2 \%$.

- This is the result of starting work on the first day of the week after the holiday on Friday and Saturday. Most of the employees, students and workers go to work, education and other places inside the Baghdad city, which is confirmed by $38 \%$ of the traffic volume coming from the axis of Shaab towards the city center.
2) According to Modes of Transportation: Table (2) shows the following:

- The percentage of passenger cars has $79 \%$, while the percentage of heavy cars $21 \%$. It is a large percentage for heavy cars which increase traffic congestion as well as increase the deterioration of roads and transport routes due to their heavy loads.

- The percentage of passenger cars has $47 \%$ at peak hour morning, while 53\% at evening peak hour.

- $\quad$ The percentage of heavy cars has $45 \%$ at peak hour during the morning, while $55 \%$ at evening peak hour.

- The highest volume of traffic for heavy cars has on Saturday, accounting for $27 \%$ of total traffic volume and the lowest traffic volume on Sunday, reaching $19 \%$. This is the result of regulatory procedures for the entry of heavy and large cars Baghdad city. The remaining days accounted for $20-24 \%$.

- Figure (3) shows that traffic volumes in the evening rush hour are more than the evening peak for passenger cars, as they grow more on Sunday, while it is converging on Monday and Tuesday, that are clearly different on Wednesday and Thursday.

Figure (4) shows that the traffic volume at evening peak time is more than the evening peak of heavy cars

\section{Passenger Car}

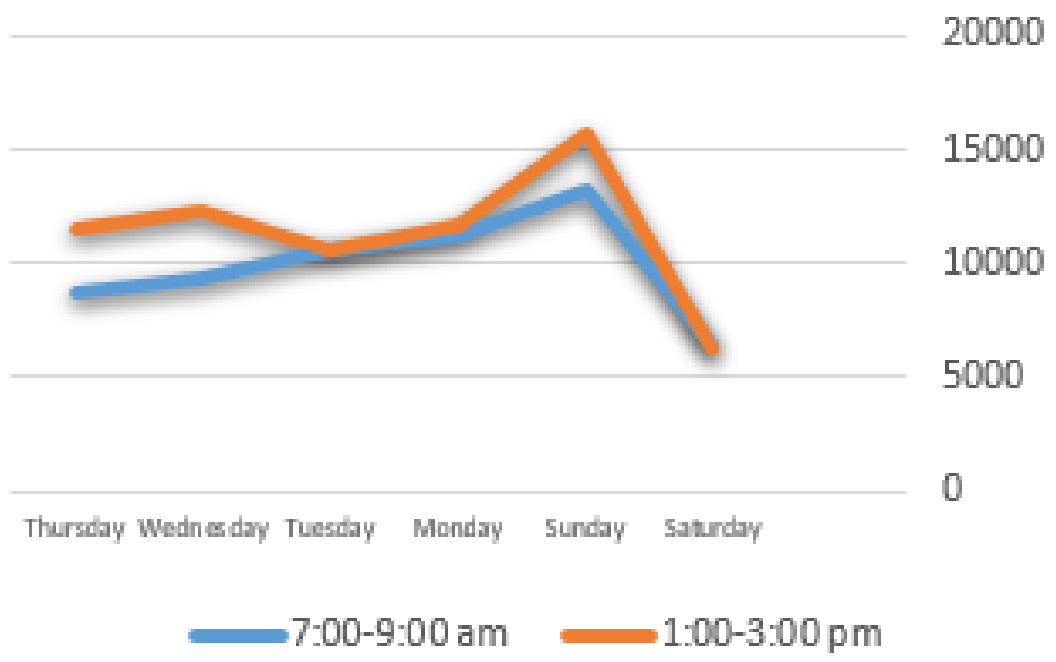

Fig. 3: The Traffic Volume in Peak Hour Morning and Evening in Case Study for Passenger Car 


\section{Heavy Car}

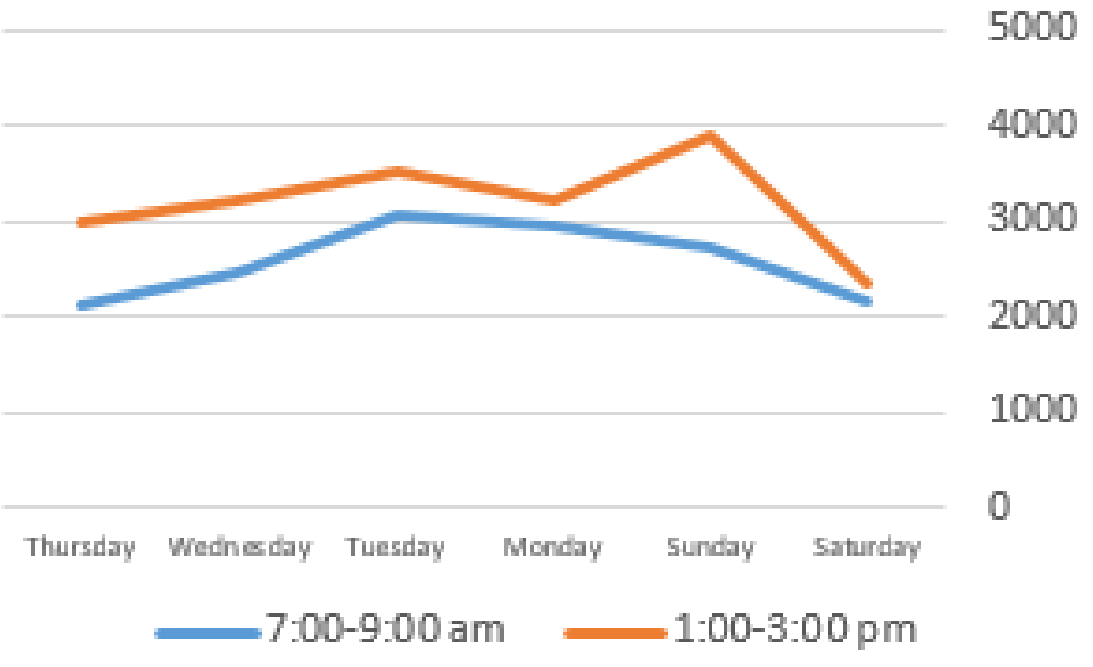

Fig. 4: The Traffic Volume in Peak Hour Morning and Evening in Case Study for Heavy Car

\begin{tabular}{|c|c|c|c|c|c|c|}
\hline \multicolumn{7}{|c|}{ Table 2: Traffic Volume in Case Study in Details } \\
\hline Mode & \multicolumn{2}{|c|}{ Passenger } & \multirow{2}{*}{$\%$} & \multicolumn{2}{|c|}{ Heavy car } & \multirow{2}{*}{$\%$} \\
\hline Time & 7:00-9:00 am & 1:00-3:00 pm & & 7:00-9:00 am & $1: 00-3: 00 \mathrm{pm}$ & \\
\hline Saturday & 6309 & 6182 & $73 \%$ & 2168 & 2353 & $27 \%$ \\
\hline Sunday & 13266 & 15683 & $81 \%$ & 2737 & 3913 & $19 \%$ \\
\hline Monday & 11242 & 11663 & $79 \%$ & 2961 & 3223 & $21 \%$ \\
\hline Tuesday & 10544 & 10615 & $76 \%$ & 3062 & 3519 & $24 \%$ \\
\hline Wednesday & 9382 & 12352 & $79 \%$ & 2477 & 3206 & $21 \%$ \\
\hline Thursday & 8776 & 11472 & $80 \%$ & 2135 & 2973 & $20 \%$ \\
\hline \multirow{3}{*}{ Total } & 59519 & 67967 & & 15540 & 19187 & \\
\hline & $47 \%$ & $53 \%$ & & $45 \%$ & $55 \%$ & \\
\hline & \multicolumn{2}{|c|}{$79 \%$} & & \multicolumn{2}{|c|}{$21 \%$} & \\
\hline \multicolumn{7}{|c|}{ Authors using HS } \\
\hline
\end{tabular}

- There is a difference between the two largest times on Sunday and the lowest on Saturday, while on a regular level on the rest of the week.

\section{Level of Service (LOS) in the Study Area}

HCS has used to determine the level of service in the study area. Through the traffic volumes of the study area, the level of service at the intersection has defined. The level of service has (F) in the main axes of the intersections (Shaab, Sulayikh, Alqanna) (F) (table 3)

It shows that the delay rate has 557.2 seconds, indicating that the intersection is characterized by traffic congestion in the peak hours of morning and evening, which requires the preparation of suggestions and treatments that depend on sustainability to reduce congestion traffic.

\begin{tabular}{|c|c|c|c|}
\hline \multicolumn{3}{|c|}{ Table 3: Lane Group Capacity, Control Delay, and LOS Determination } \\
\hline & ALQANNA & SHAAB & SELEKH \\
\hline Adjusted Flow Rate & 2540 & 2906 & 2579 \\
\hline Lane Group Capacity & 2039 & 2111 & 2258 \\
\hline v/c Ratio & 1.25 & 1.38 & 1.14 \\
\hline Green Ratio & 0.50 & 0.50 & 0.50 \\
\hline Uniform Delay d1 & 0.5 & 0.5 & 0.5 \\
\hline Delay Factor k & 0.50 & 0.50 & 0.50 \\
\hline
\end{tabular}




\begin{tabular}{|c|c|c|c|}
\hline Incremental Delay d2 & 446.7 & 681.0 & 262.1 \\
\hline PF Factor & 1.000 & 1.000 & 1.000 \\
\hline Control Delay & 563.7 & 739.5 & 345.5 \\
\hline Lane Group LOS & $\mathrm{F}$ & $\mathrm{F}$ & $\mathrm{F}$ \\
\hline Approach Delay & 563.7 & 739.5 & $\mathrm{~F}$ \\
\hline Approach LOS & $\mathrm{F}$ & Intersection LOS & $\mathrm{F}$ \\
\hline Intersection Delay & 557.2 & \multicolumn{2}{|c|}{ Authors using HSC } \\
\hline \multicolumn{2}{|r}{}
\end{tabular}

\section{Causes of Traffic Congestion in the Intersection Through the Results of Analysis}

1) Truck and heavy cars $(21 \%)$ represent the most important factors for increasing for overcrowding in the study area, which is increasing during peak evening hours, which requires procedures it reduces their entry to the Baghdad city in general and the study area especially.

2) The study area represents the most important entrance to the Baghdad city and the city center, which is attributed to increase traffic congestion due to the high traffic density and increase the number of cars, especially private cars.

3) The different land uses (administrative, commercial, industrial, educational, health and others) focused on the city center of Baghdad along the axis passing through the study area, which showed that the study area is the link between the work and housing areas, which requires regulation of land uses in the work and housing areas.

4) Land use, education, health and other areas of the accommodation, which increases the distance and time of flights, which require for bringing them closer together to reduce the number of trips and reduce their travel.

5) Impact of traffic and flight is coming from outside the Baghdad city on the study area, causing increased traffic congestion.

6) Lack of legal and regulatory determinants of the transport and traffic sector for increasing traffic congestion.

7) Weak attention to public transport, poor performance, efficiency and lack of multiple modes of transport.

\section{Implementation of Sustainable Transport Strategies in the Study Area (Al Shaab - Sulayikh)}

\section{First: Avoid Strategy:}

Requires the implementation of strategy avoidance to long distances and future plans to address the problems of land uses that cause increased traffic congestion in the
Baghdad cityin general and the study area in particular, as follows:

1) Regional Side: The Baghdad city suffers from an increase in the number of vehicles outside the city from all its entrances, especially the passengers in the study area (Al-Shaab junction) for work, education, health, administrative reviews and others. This increases traffic congestion at the intersection of the passage of the flights and the direction of the city center. The project proposes the following (Figure 5):

A) activation and the establishment of economic activities for the cities of the city of Baghdad, including the city of Husseiniya, Rashidiya and Taji and the surrounding areas, to reduce flights from sources to the city of Baghdad, to bring the workplaces of housing

B) Establishing commercial zones and commercial stores near the disciple's cities to activate the area economically and prevent the heavy cars from entering the city of Baghdad, especially that $21 \%$ of the traffic volumes in the study area are cars of pregnancy

C) The establishment of recreational and tourist areas near the regional border administrative district of Baghdad and Diyala is working to attract flights for coming from the province of Diyala and its neighboring provinces for entertainment, as well as flights out of Baghdad towards these areas.

D) Increasing the administrative uses and increasing the powers in the cities of the disciples such as Hasiniyah and others.

E) To increase the activation of the role of administrative decentralization of the provinces and transfer the powers of ministries and government institutions to the provinces in order to reduce the regional flights coming to the city of Baghdad.

The establishment of a track for the rapid train stretching from the city of Husseiniya to the center of Baghdad is working to reduce the use of private cars entering the Baghdad city and reduce the trips passing through the study area 


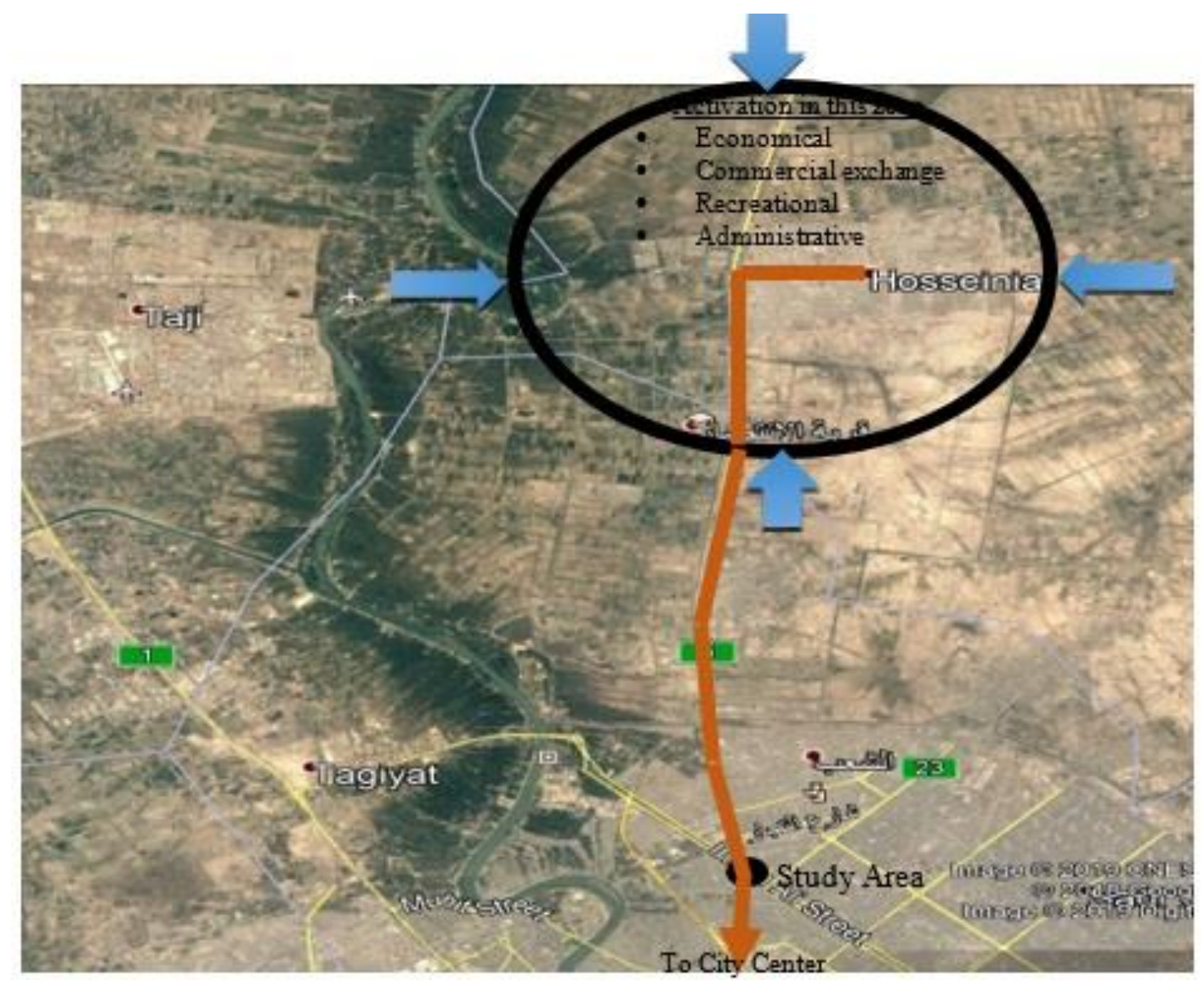

Fig. 5: Regional Proposals for Avoidance Strategy. Authors using Google Earth

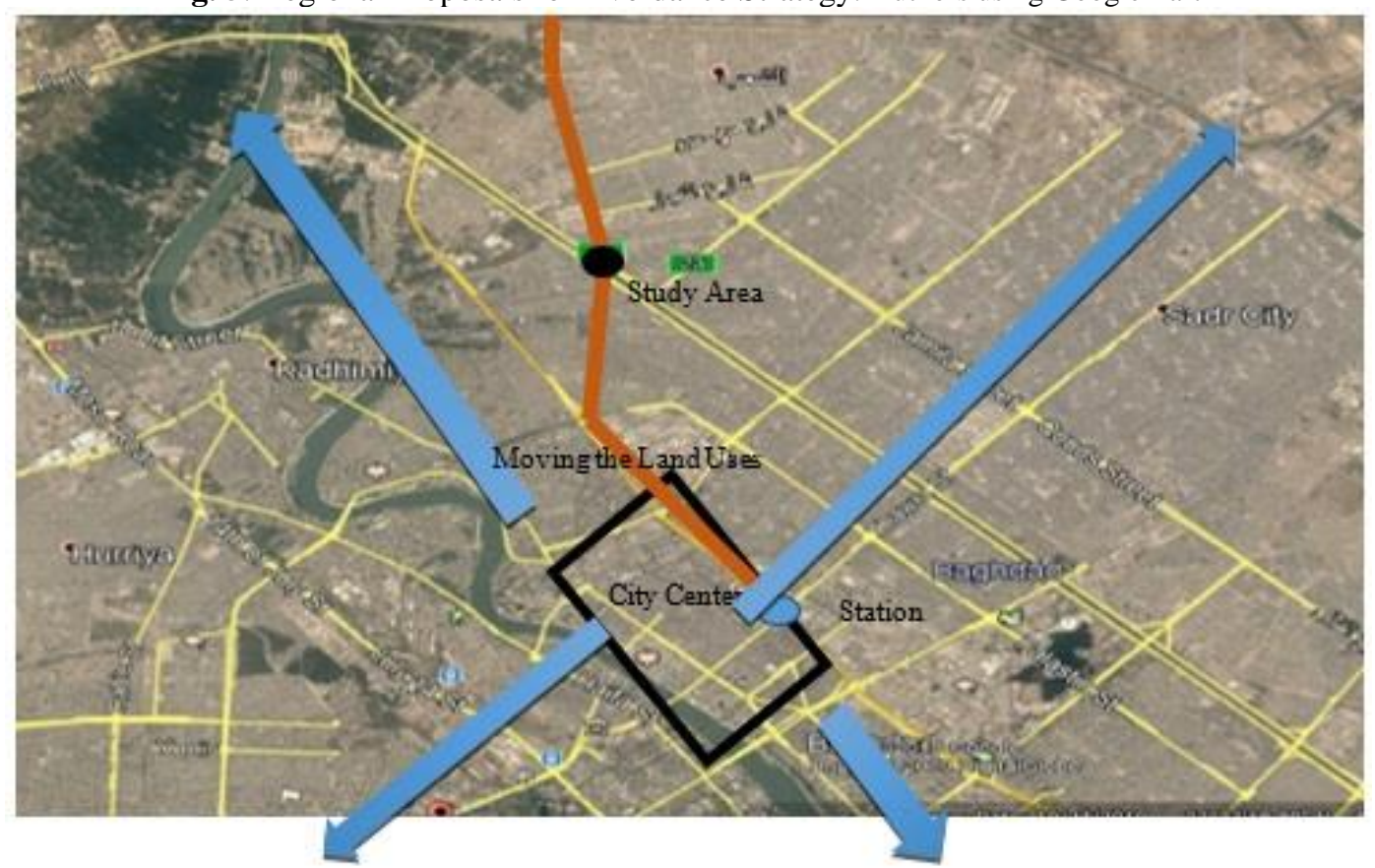

Fig. 6: Urban Proposals for Avoidance Strategy (land use transfer). Authors using Google Earth

2) Urban Side: The city of Baghdad, especially the center of the city, suffers from the concentration of commercial, industrial, educational, health, administrative, recreational and other uses of the land, which increase the attraction of flights, as the intersection of the Saab - Selekh which is one of the main axes of transport and shortened towards the center of the Baghdad city coming from outside the city of Baghdad. The project proposes the following:

A) Transfer The use of the industrial land, warehouses and non-suitable for the master plan in the center of the 
Baghdad city to specific areas and planned in the outskirts of the Baghdad city to reduce the attraction

of flights generating the traps (Figure 6).

B) transfer of land that uses attractive trips such as education and administrative, transport out of the Baghdad city, distributed in a balanced way for trips out and entering to the city of Baghdad.

C) Re-planning the centers of the district and residential neighborhoods in Baghdad city, especially in the Shaab district and neighboring, turning them into development centers with mixed land uses, to increase activities in these centers and bring them closer to their inhabitants and thus reduce the travels generated from these centers to the rest of the areas of Baghdad and the city center through the study area

D) Build up Public transport stations in the centers of residential shops following the development of transport oriented (TOD) with multiple public transport modes serving $600 \mathrm{~m}$ walk. These stations are interconnected to be a network directly connected with the high-speed train which connects the city center with satellites cities (Figure 7).

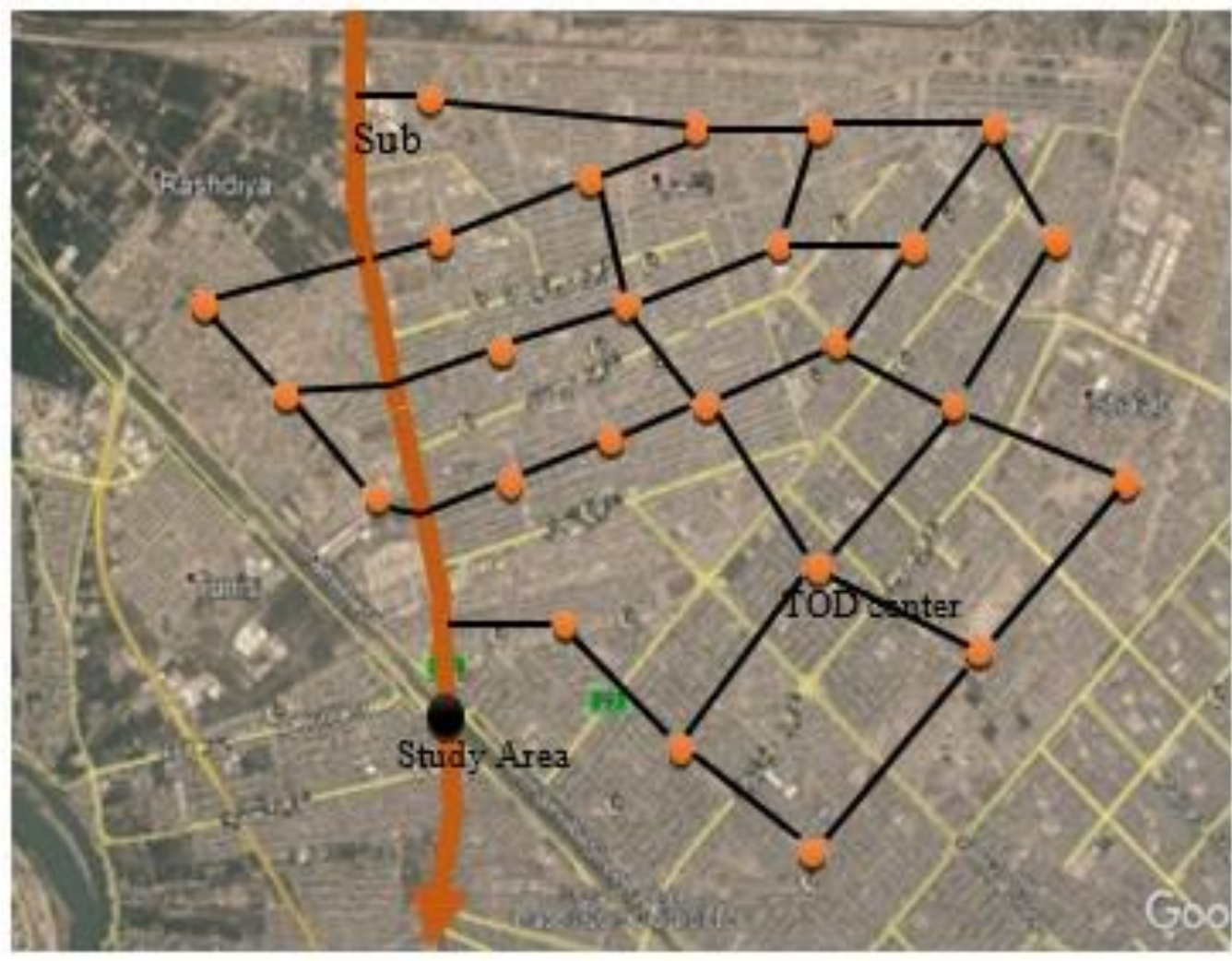

Fig. 7: Proposals for the Re-planning of Residential Neighborhoods by Adoption of TOD. Authors

E) Organization commercial axis extending from the city center to the city of the Shaab by changing the use of commercial land to mixed use within the stations of public transport subsidiary associated with public transport stations in residential neighborhoods.

The avoidance strategy can be implemented within the long, medium- and near-term plans, as these proposals can be divided according to applicable time periods

\section{Second: Shift Strategy}

The transformation strategy focuses on multiple modes of transport and switching from one mode to another. The most important proposals are:

1) Regional Side: The project proposes the following:
A) Use bus rapid transit (BRT) for users from outside the city of Baghdad, whether from other cities or provinces, through the following:

- Increase the restrictions on the entry of private cars to Baghdad city as a fee for private cars entering the Baghdad city to reduce the entry of cars to the city and thus reduce the congestion traffic in the city.

- The establishment of a parking lot in the area of Bob Sham for the purpose of private parking and move to the modes of rapid transport system and transfer users to the city of Baghdad.

- The possibility of linking public transport systems such as suspended tracks and other parking to implement 
the policy (park - ride) to increase the diversity of transport modes.

Use the proposed train in the strategy of avoidance and linking it with the proposed parking in the area of Bob Al-
Sham to increase the diversity of public transport entering the Baghdad city (Figure 8)

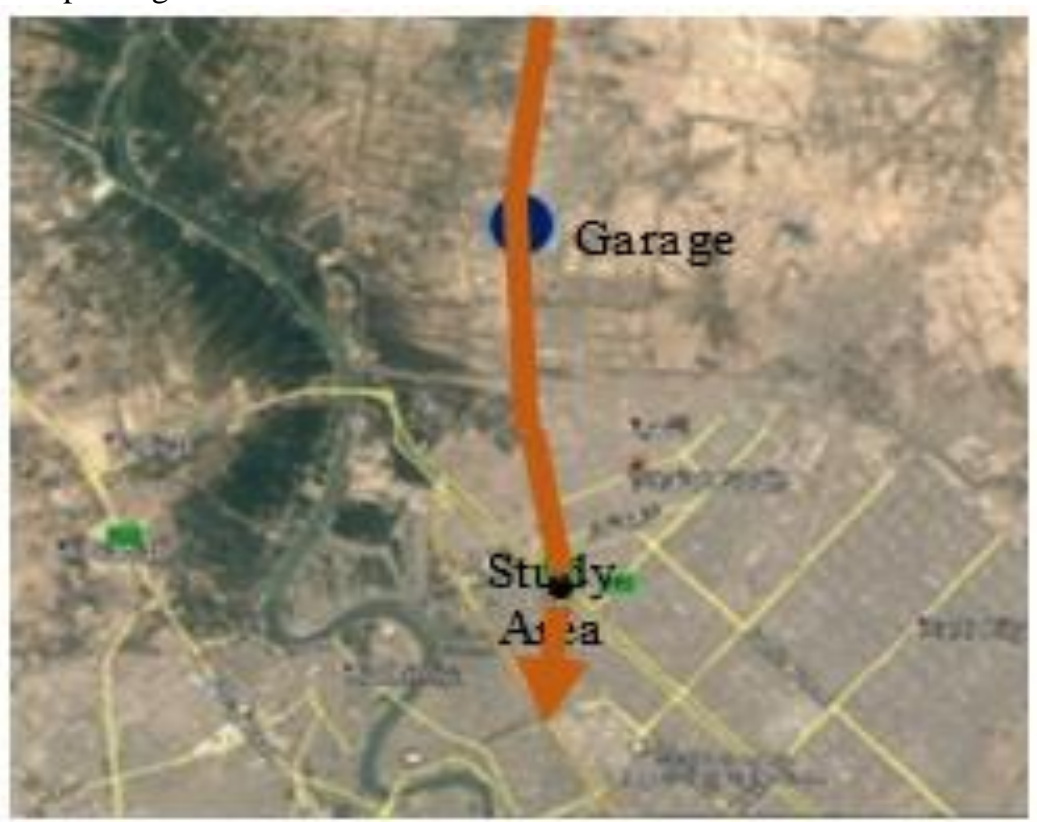

Fig. 8: Regional Proposals for the Transformation Strategy. Authors using Google Earth

2) Urban Side: The project proposes the following:

A) Re planning the main artery extending from the people area to the city center through:

- The allocation of the middle track of public transport by two levels, by allocating the ground level for public transport vehicles, buses and the upper level suspended for the outstanding highways.
- Two routes for non-motorized vehicles, such as bicycles and pedestrians, are assigned to each side, with improv security and climatic paths such as tree planting, street furniture to provide an encouraging environment for walking and cycling.

- The allocation of transit stations on the main artery connects the stations (TOD), and it has proposed public transport from outside the city limits of Baghdad to the city center (Figure 9).

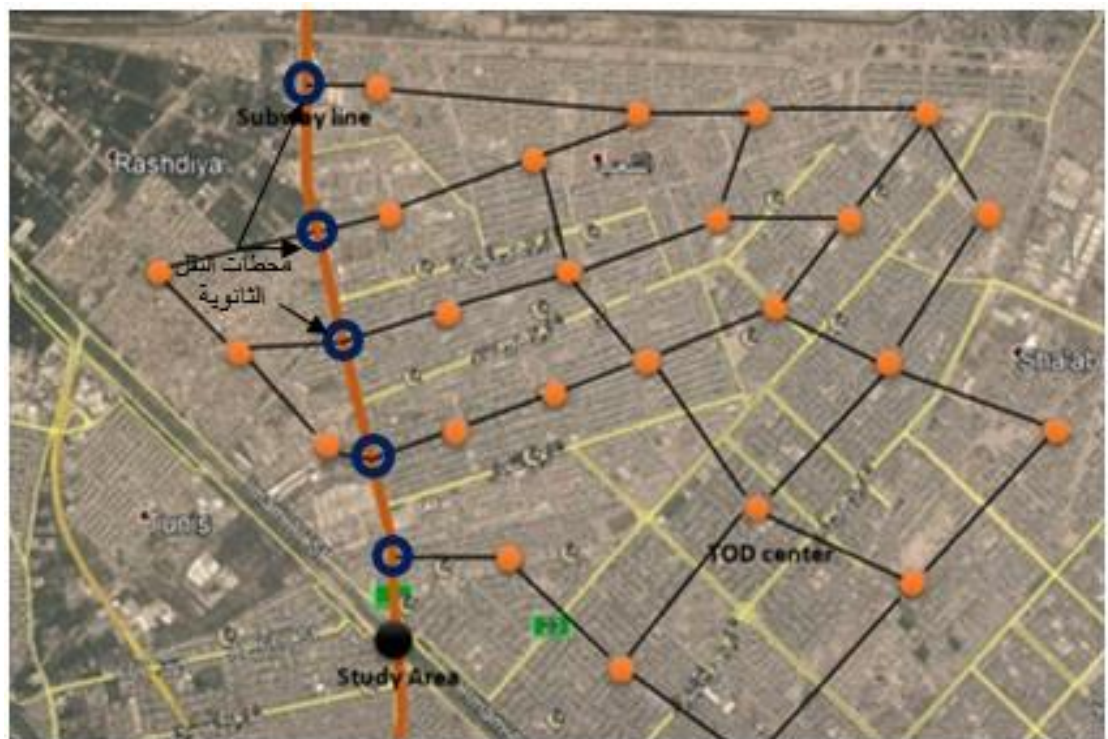

Fig. 15: Proposed Locations for Secondary Transport Stations. Authors using Google Earth 
B) Planning centers (TOD) In a manner that encourages the use of bicycles and pedestrians for a radius of $500 \mathrm{~m}$, with the reorganization of land uses in the center and encouraging mixed uses.

C) Select entry of private cars to the city center of Baghdad models not exceeding 5 years on the manufacture of the purpose of reducing the flights entering the Baghdad city in general and the city center in particular.

D) Create a train track to transport goods from the areas of trade and stores outside the Baghdad city to commercial stores proposed by the Secretariat of Baghdad to the outskirts of Baghdad to reduce the entry of large and small load cars, which represent about $20-30 \%$.

The transformation strategy can be implemented within the near and mid-range transport plans within a hierarchy of plans implementation

\section{Third: Improve Strategy}

The improvement strategy focuses on the technological and information aspects of the transport sector in order to improve the traffic and environmental performance of the city through:

1) Application of Intelligent Transfer System (ITS) In the study area for the purpose of regulating traffic and minimizing traffic congestion through the following:

- Install the digital screens with variable signals in the study area to give the traffic indicators in the study area and give alternatives to road users to reduce congestion traffic.

- $\quad$ The establishment of a radio network in the study area and in Baghdad in general gives road indicators periodically and can be used through the radios inside the car to guide the road users busy or empty roads.

- Establishing an integrated system to connect cars to the system (GIS)

With central control to guide road users by following guidelines and instructions that reduce congestion.

- The establishment of a network of traffic signs to guide road users and not to interfere with the instructions and traffic guidelines that lead to congestion and congestion traffic in the study area.

2) Restrict private cars has used for fossil fuels from entering the city center thus reducing congestion in the study area.

The improve strategy can be implemented within shortterm plans in the study area to reduce congestion

\section{Forth: Protection Strategy}

The protection strategy focuses on the technological and information aspects of the transport sector in order to improve the traffic and environmental performance of the city through:

1) Legislation of laws and regulations reduce the use of private cars such as increasing taxes, fees and preparing timetables to regulate traffic, thus improving traffic safety and reducing trips.

2) Preparation of awareness and cultural awareness and cultural courses in the negative impacts of traffic congestion from the environmental, economic and health aspects of the city of Baghdad.

The protection strategy can be implemented within planning plans in the study area to reduce traffic congestion

\section{Conclusions}

1) The entrances to the Baghdad city are of great importance in organizing the transport and traffic in the city of Baghdad, as it effectively affects the increase in traffic congestion in the city, especially near the city center such as the intersection of Sha'ab-Selekh.

2) Heavy vehicles and trucks represent a great and influential challenge to the Baghdad city as a whole, especially after the increasing numbers and the concentration of commercial and industrial stores inside the city of Baghdad, causing increased congestion and traffic jams As well as the increasing deterioration of roads inside and outside the city of Baghdad, and the proposed strategies to reduce the volume of traffic by $21 \%$ for heavy vehicles.

3) The impact of the regional side on the Baghdad city and the broad impact to include all Iraqi provinces and maintain its concentration and dominance despite the application of administrative decentralization in the administration of Iraqi provinces.

4) One of the modes of public transport in the Baghdad city and the weakness of efficiency has caused the increase of congestion traffic in the Baghdad city in general and the study area in particular.

5) Changing the land use of the Baghdad city from residential use to commercial, industrial and other uses in the study area and the city center caused a change in transport planning and the generation and increase of trips without prior planning.

6) The two sides of the study area extending from the axis from the beginning of the entrance of the Baghdad city in the area of Shaab and crossing the study area to the center of the city the most important reasons for increasing traffic congestion at the intersection as a result of changing 
land uses from residential to commercial use, which cause increased traffic congestion in the region.

\section{Recommendations}

1) Prepare a timetable for the implementation of the proposals in the research have divided according to time periods ranging from one year to 10 years starting from the implementation of the protection strategy first to the possibility of application through awareness campaigns and education and legislation laws and legislation governing the process of transport and traffic inside and outside Baghdad. As well as the implementation of the strategy of improvement in a period not exceeding the year for ease of application in the current term through the application of intelligent transport system in the streets and roads of Baghdad.

2) The strategy of avoidance and transformation to improves the level of service reduce congestion in the study area needs short- and medium-term plans for the purpose of regulating land use and integrating it with sustainable transport planning.

3) Rehabilitation of the engineering aspects of the intersection by activating the work of traffic signals and improving the tiling and tracks in a precise technical manner.

\section{References}

[1] Wang, Lingli (2014) "Framework for Evaluating Sustainability of Transport System in Megalopolis and its Application" ScienceDirect, Elsevier, 2014 International Conference on Environment Systems Science and Engineering, IERI Procedia 9, p. $110-116$.

[2] Litman, Todd (2018) "Well Measured: Developing Indicators for Sustainable and Livable Transport Planning" Victoria Transport Policy Institute, p. 8.
[3] United Nations, Bureau International Des Expositions, Shanghai 2010 World Exposition Executive Committee (2013) "Shanghai Manual: A Guide for Sustainable Urban Development in the 21st Century" General for the Conference on Sustainable Development (Rio+20), pp. 3637.

[4] Tumlin, Jeffrey (2012) "Sustainable transportation planning: tools for creating vibrant, healthy, and resilient communities" John Wiley \& Sons, New Jersey, USA, p. 120.

[5] Gudmundsson, Henrik, Hall, Ralph P., Marsden, Greg \& Zietsman, Josias (2016) "Sustainable Transportation: Indicators, Frameworks, and Performance Management" Springer-Verlag Berlin Heidelberg, New York, USA, p. 61.

[6] Abdulwahab, Areej Muhy \& Ismael, Nabil T. \& AlNuaimi, Saad Fawzi (2018) "Institutional Framework Sustainable Transportation for Iraq" IEEE, 2018 International Conference on Advanced Science and Engineering (ICOASE), Kurdistan Region, Iraq, p. 485.

[7] Abdulwahab, Areej Muhy (2017) "Future Transport Strategies for Major Cities: The City of Baghdad in 2030" Diyala Journal of Engineering Sciences, Vol. 10, No. 2, p. 35.

[8] Zehawi, Raquim N. \& Ahmed, Qusay W. (2018) “A System Dynamics Simulation to Estimate Roundabout Entry Capacity by Adopting Three Different Methods" Diyala Journal of Engineering Sciences, Vo. 11, No. 4, p. 35 .

[9] Huangm Han-Way (2010) "HCS12 / 9S12: An Introduction to Software and Hardware Interfacing" 2nd Edition, Delmar, Cengage Learning, USA 